NASA Technical Memorandum 86993

\title{
Film and Interstitial Formation of Metals in Plasma-Sprayed Ceramics
}

R.C. Hendricks and G. McDonald

Lewis Research Center

Cleveland, Ohio

and

R.L. Mullen

Case Western Reserve University

Cleveland, Ohio

Prepared for the

12th International Conference on Metallurgical Coatings sponsored by the American Vacuum Society Los Angeles, California, April 15-19, 1985 
FILM AND INTERSTITIAL FORMATION OF

\title{
METALS IN PLASMA-SPRAYED CERAMICS
}

\author{
R.C. Hendricks and G. McDonald \\ National Aeronautics and Space Administration \\ Lewis Research Center \\ Cleveland, Ohio 44135 \\ R.L. Mullen \\ Case Western Reserve University \\ Dept. of Civil Engineering \\ Cleveland, ohio 44106
}

ABSTRACT

A method is described to electrodeposit noble metals such as platinum and ordinary metals such as copper on and within plasma-sprayed ceramic materials and ceramic fiber materials. Low-density ceramic fiber bodies were vacuum impregnated with plating solution and attached to an electrode. Light micrographs illustrating the density and location of deposited materials are presented and discussed. Voids in the plasma-sprayed ceramic were filled with deposits that vary from spherical to lens-shaped acircular and have particle size corresponding to the full range of void size. Multiple coatings of ceramic and metal can be sequenced.

\section{INTRODUCTION}

Excessive interface strains are recognized as a mechanism for ceramic coating fallures (Ref. 1). Rocket engine thrust chambers fabricated by using the "inside out" process, whereby ceramic is placed on a mandrel and closed out by electroplating and milling, 1llustrate the effectiveness of thin ceramic liners in severe thermal environments (Ref. 2).

The deposition of material within the ceramic appears to mitigate interface strains while forming a structure. The component can then be processed by heat treating, isostatic pressing, etc., to further enhance its 
properties. Multiple coatings of either ceramic or metal can be sequenced if the materials are compatible.

In this paper we discuss the electrodeposition of metaliic materials within and on the surface of plasma-sprayed ceramics and associated problems.

\section{RESULTS AND DISCUSSION}

Ceramics can be plasma-sprayed onto mandrels and then stripped (Refs. 3 and 4). Rejoining the two halves of the ceramic by electroplating a metal can be difficult when residual ceramic strains are not accounted for (Ref. 5). Further difficulties arise when the ceramic surface is unprotected by masking, as deposits can form on and within the ceramic (Fig. 1, right side of ring).

Figure 2 illustrates the electrodeposition of copper on the surface of the ceramic. The ceramic and the metallic bond coat were plasma sprayed over a superalloy substrate rod. The substrate cathode and the copper-tube anode were placed in an electrolyte bath, nominally $210 \mathrm{~g} / 1$ iter $(28 \mathrm{oz} / \mathrm{gal})$ of $\mathrm{CuSO}_{4}$ with $52 \mathrm{~g} / 1$ iter $(7 \mathrm{oz} / \mathrm{gal})$ of $\mathrm{H}_{2} \mathrm{SO}_{4}$, and connected to a regulated direct-current power supply. There is no evidence of copper deposition within the ceramic for high- or low-porosity ceramic coatings (Fig. 2). Because the plating solution was an aqueous acid, the "micropower" should have been sufficient to penetrate the porous ceramic. We speculate that the overvoltage was excessive and caused reduction at the extreme ceramic-electrolyte interface. 1 The copper layed down was nonhomogeneous (tree-like) in structure for both porosities.

At a lower plating voltage the electrodeposition interface appeared to move toward the bond coat/ceramic interface. Although the tortuosity of the ceramic was large and metallic formations were 111 defined, there was little,

1The porosity and tortuosity of the ceramic alters the conductance. Even assuming that Hittrof's rule applies and that transmittance is given by the Kohlrausch-Onsager relationship, we could not determine the nature of the cell. 
if any, evidence to suggest a direct connection between the deposited copper and the metallic bond coat (Fig. 3). At $\times 100$ (Fig. 3(a)) the void-filling copper islands were prominent with evidence of circumferential layering, a characteristic of the plasma-spray splat-quench. Figure $3(b)$ at $\times 200$ better 1llustrates the deposition patterns, which vary from spherical to lens-shaped acircular with a range in particle size. Both figures illustrate a segregation of copper near the bond coat/ceramic interface with a tough layering of copper plating over the exterior ceramic interface. But no direct connections to the metallic bond coat are evidenced. This, again, suggests a possible overvoltage with insufficient throwing power to penetrate to the interface and with reduction occurring within the porous ceramic structure.

Platinum was plated within and on the ceramic in a manner similar to that for copper but probably with acid dissolution of the bond coat. The cathode, a ceramic-coated rod, and the platinum anode were placed into an electrolytic bath, nominally 0.1 molar aqueous platinum chloride solution. A platinum nodule on the ceramic exterior developed with nonuniform interstitial deposition of platinum (Fig. 4(a)). Circumferential layering and marbling were significant (Fig. $4(\mathrm{~b})$ ), and there was some evidence of marbled connections to the vacant interstitial area between the ceramic and the substrate. However, there was no evidence of platinum plating of the substrate. We believe the metallic bond coat dissolved, but it may have been reduced.

Fibrous ceramic materials (Ref. 6) are difficult to coat and form into a high-strength component. A copper-wire cathode was stuck into a block of $\mathrm{SiO}_{2}$ fibrous material and, along with a copper anode, placed into the aqueous $\mathrm{CuSO}_{4}-\mathrm{H}_{2} \mathrm{SO}_{4}$ solution. In this case the micropower was insufficient to effect any perceptible deposition even to $40 \mathrm{~V} d c$. Placing a fibrous $\mathrm{SiO}_{2}$ block in the electrolyte solution within a vacuum decanter lowered the pressure and 
permitted outgassing to the bolling point. The vacuum-impregnated fibrous $\mathrm{SiO}_{2}$ was then plated. The plating was rough and nonuniform (Fig. 5). The $\mathrm{SiO}_{2}$ outer surface characteristics (Fig. 5(a)) appear as impaled particles. Etching showed the nature of the subsurface structuring in more detail (Fig. 5(b)). The apparent air voids displaced by vacuum impregnation appeared as interstitial copper fibers. Because fibrous materials have a lay, the sections would appear different along different cutting planes.

The high ion mobility of aqueous acid solutions, characteristic in heat engine cycles, permits ion penetration of plasma-sprayed ceramic and improper bond coats. Oxidation at the bond coat/ceramic interface delaminates the ceramic (Ref. 7), and inadequate porosity control in the bond coat permits significant substructure degradation (Ref. 8 ).

\section{SUMMARY}

Electrodeposition of copper and platinum within, and on the exterior surface of, plasma-sprayed ceramic materials has been demonstrated. Although details of the process are not understood, we speculate the existence of a hydrogen cell reaction, with reduction taking place within the ceramic and outside the metallic ceramic interface.

The high ion mobility in aqueous acid solutions, characteristic in heat engine cycles, permits ion penetration of both plasma-sprayed ceramic and improper bond coats and leads to delamination and substructure "hollowing." It is anticipated that the process could be applied in manufacturing catalytic converters, batteries, high-temperature, low-maintenance elements (e.g., bearings), and furnace and welding electrodes and in the electrolytic production of gases.

The authors wish to thank Mr. F.J. Trepka for performing scanning electron microscope (SEM) and wavelength dispersive spectrometer (WDS) work. 


\section{REFERENCES}

1. McDonald, G. and Hendricks, R.C., Thin Solid Films, 73, 491 (1980).

2. Quentmeyer, R.J., Kasper, H.J., and Kazaroff, J.M., "Investigation of the Effect of Ceramic Coatings on Rocket Thrust Chamber Life," AIAA Paper 78-1034, July 1978.

3. Hendricks, R.C., McDonald, G., and Bill, R.C., Ceram. Eng. Sct. Proc., $\underline{3}$, $750(1982)$.

4. Mullen, R.L., McDonald, G., Hendricks, R.C., and Hofle, M., Ceram. Eng. Sc1. Proc., 4, $810(1983)$.

5. Quentmeyer, R.J., McDonald, G., and Hendricks, R.C., "Fabrication of Ceramic Substrate Reinforced and Free Forms," To be presented at International Conference on Metallurgical Coatings, Los Angeles, CA, Apri1 15-19, 1985.

6. Hendricks, R.C. and McDonald, G., Ceram. Eng. Sci. Proc., 3, 744 (1982).

7. Miller, R.A., "Analysis of the Response of a Thermal Barrier Coating to Sodium- and Vanadium-Doped Combustion Gases," NASA TM-79205, 1979.

8. Shankar, S., Koenig, D.E., and Dard1, L.E., J. Met., 33 [10] 12 (1981) (also private communication, with Eliot Lassow, of Howmet Turbine Components Corp., Whiteha11, MI.) 


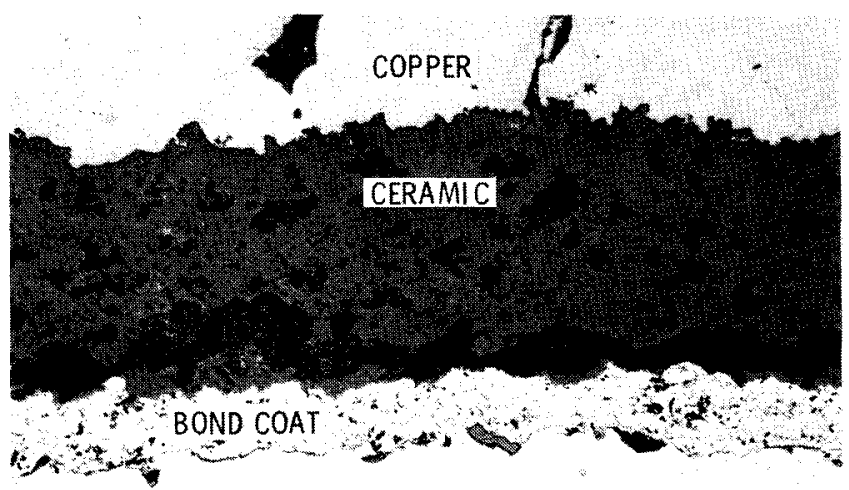

SUBSTRATE

(a) High-porosity ceramic. X100.

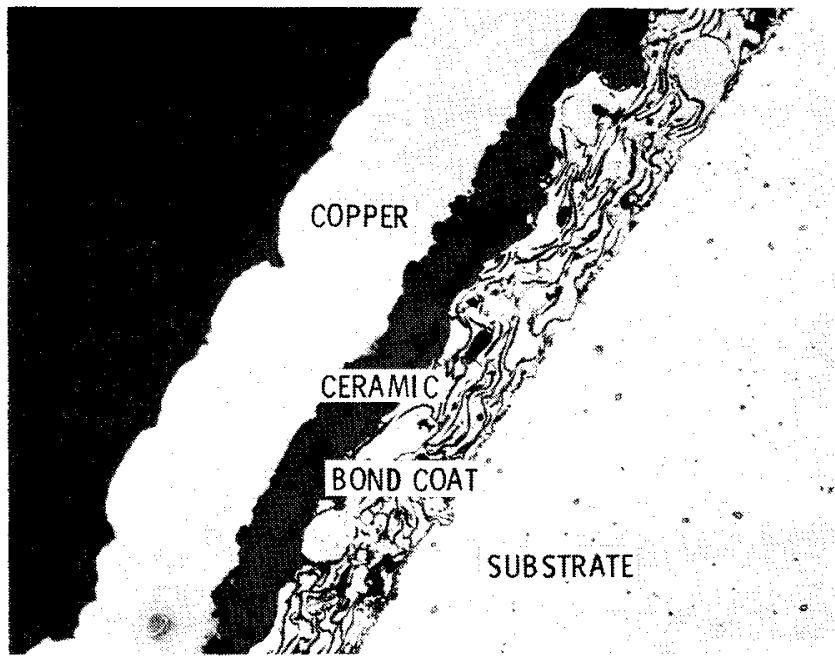

(b) Low-porosity ceramic. X100.

Figure 2. - Deposition of copper on ceramic surface without interstitial deposition. 


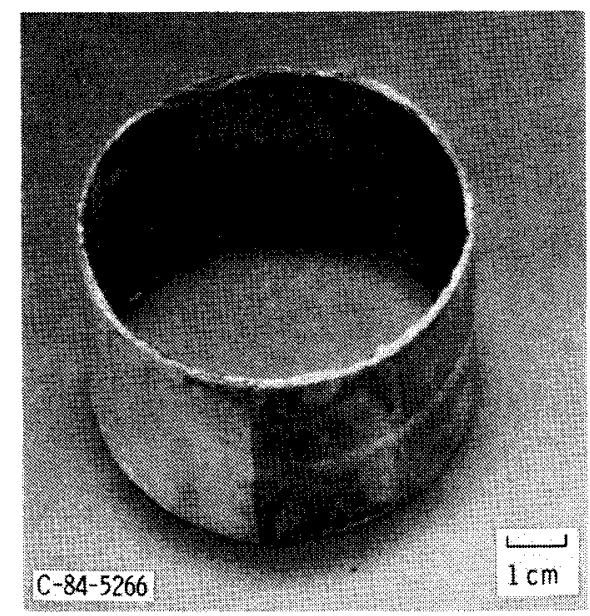

Figure 1, - Masked and unmasked ceramiccoated ring halves rejoined by copper plating. 


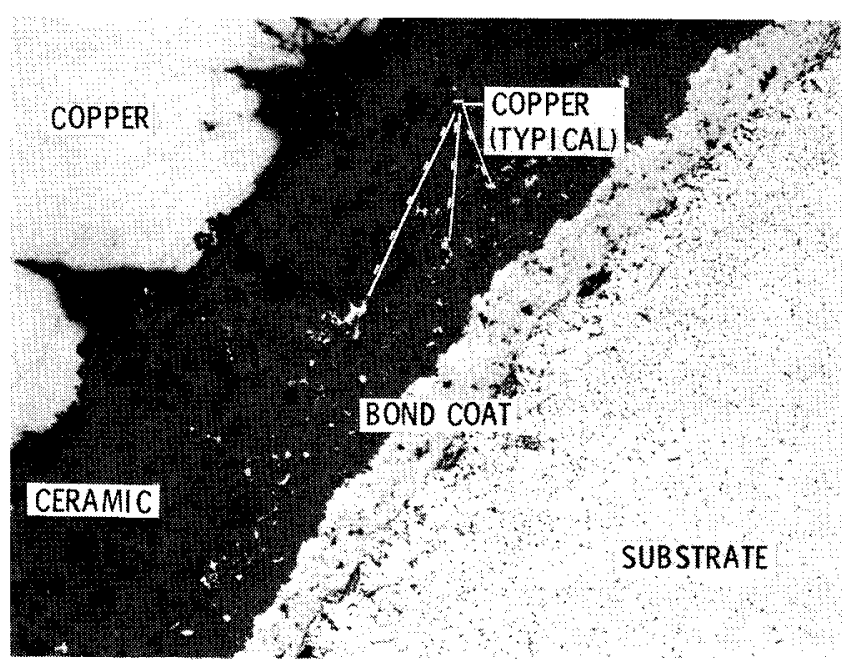

(a) $\mathrm{X} 100$.

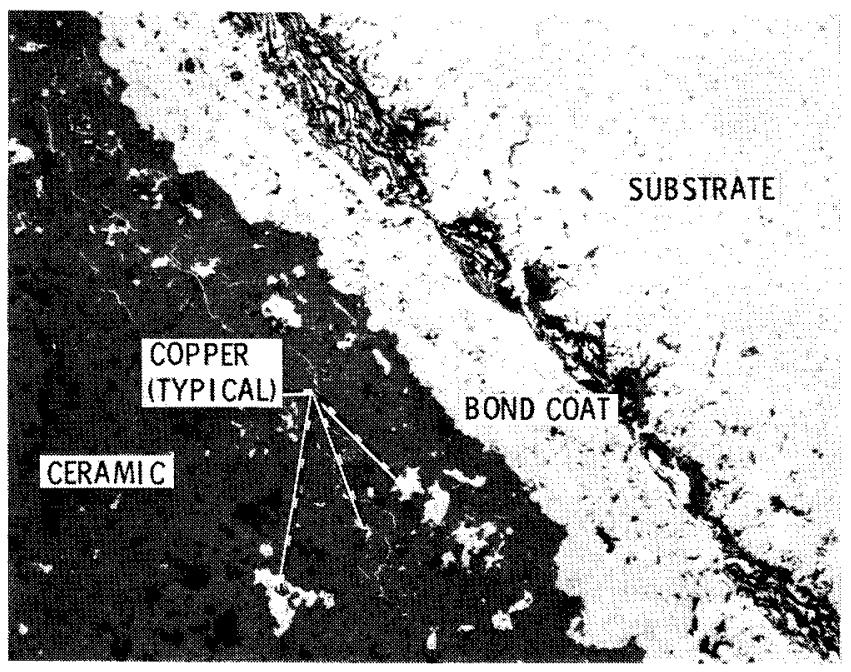

(b) $\times 200$.

Figure 3. - Nonuniform interstitial copper deposition within ceramic with surface buildup. 


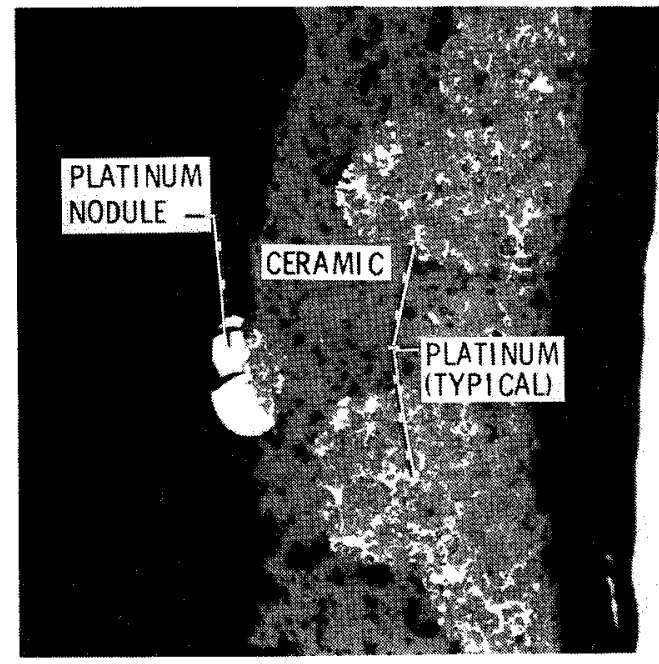

SUBSTRATE

(a) With surface nodule. $X 100$.

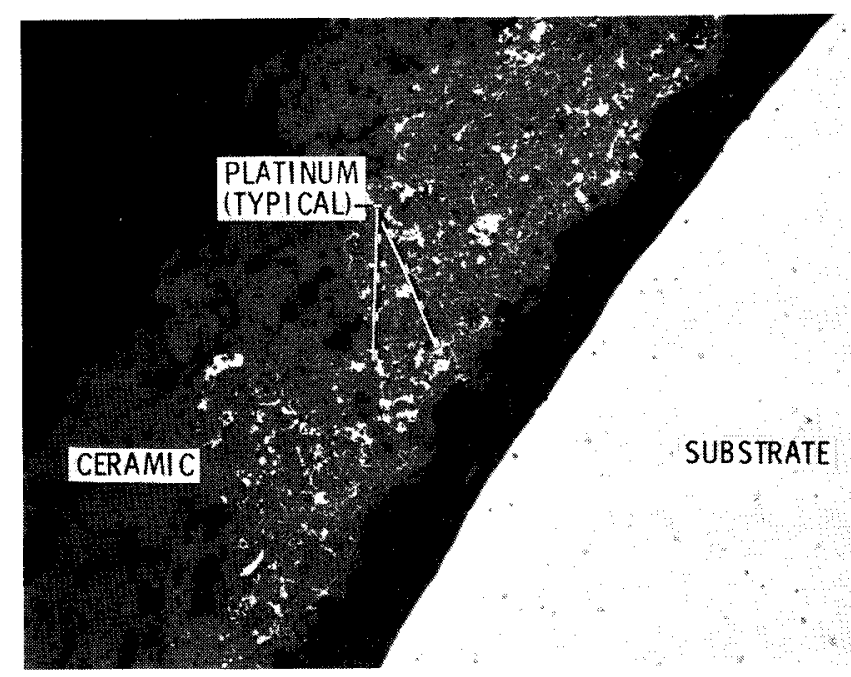

(b) Without surface deposition. X100.

Figure 4. - Nonuniform interstitial platinu m deposition within ceramic with bond coat depletion. 


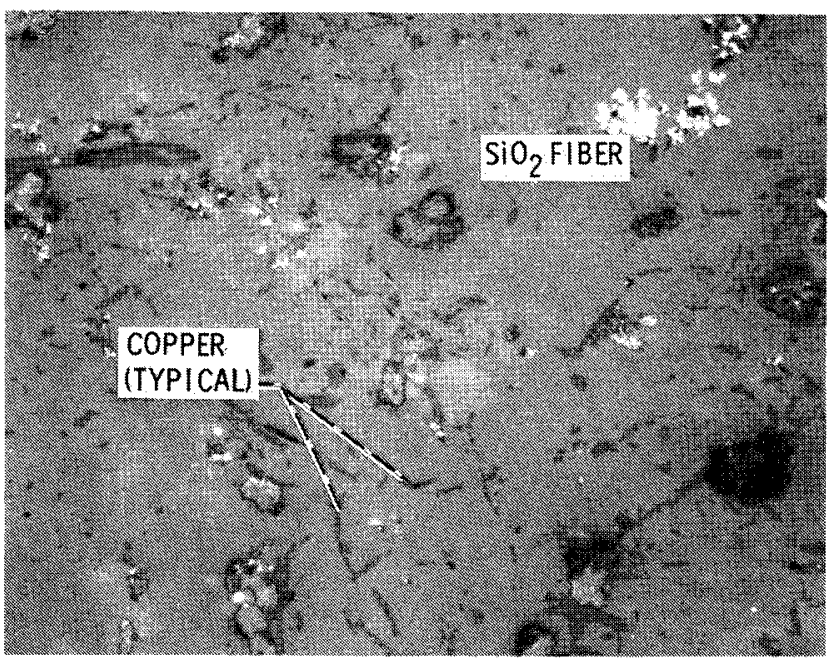

(a) Surface characteristics. X200.

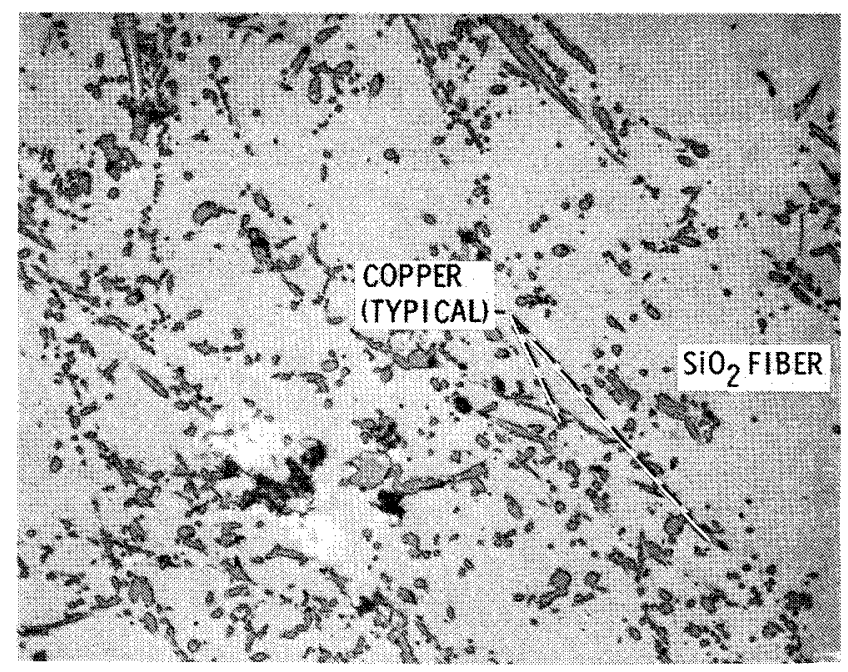

(b) Subsurface characteristics by etching. $X 200$.

Figure 5. - Copper deposition on and within fibrous ceramic. 


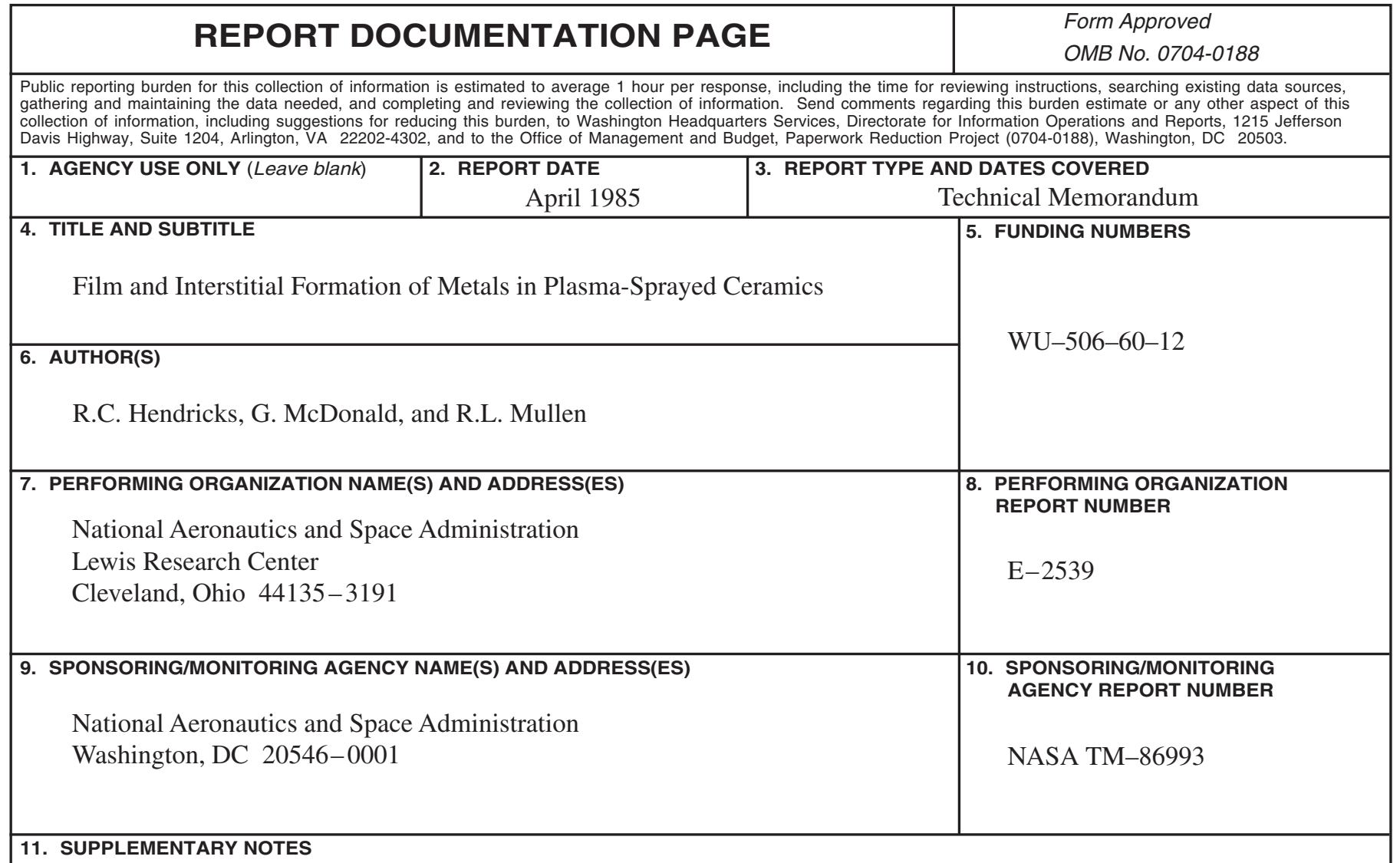

Prepared for the 12th International Conference on Metallurgical Coatings sponsored by the American Vacuum Society, Los Angeles, California, April 15-19, 1985. R.C. Hendricks and G. McDonald, NASA Lewis Research Center;

R.L. Mullen, Case Western Reserve University, Department of Civil Engineering, Cleveland, Ohio 44106.

Responsible person, R.C. Hendricks, organization code R, 216-977-7507.

\begin{tabular}{|l|l|}
\hline 12a. DISTRIBUTION/AVAILABILITY STATEMENT & 12b. DISTRIBUTION CODE
\end{tabular}

Unclassified - Unlimited

Subject Category: 27

Available electronically at http://gltrs.grc.nasa.gov

This publication is available from the NASA Center for AeroSpace Information, 301-621-0390.

13. ABSTRACT (Maximum 200 words)

A method is described to electrodeposit noble metals such as platinum and ordinary metals such as copper on and within plasma-sprayed ceramic materials. Low-density ceramic fiber bodies were vacuum impregnated with plating solution and attached to an electrode. Light micrographs illustrating the density and location of deposited materials are presented and discussed. Voids in the plasma-sprayed ceramic were filled with deposits that vary from spherical to lens-shaped acircular and have particle size corresponding to the full range of void size. Multiple coatings of ceramic and metal can be sequenced.

\begin{tabular}{|c|c|c|}
\hline \multicolumn{3}{|c|}{ Plasma spraying; Ceramics; Coatings; Electroplati } \\
\hline $\begin{array}{l}\text { 17. SECURITY CLASSIFICATION } \\
\text { OF REPORT } \\
\text { Unclassified }\end{array}$ & $\begin{array}{l}\text { 18. SECURITY CLASSIFICATION } \\
\text { OF THIS PAGE } \\
\text { Unclassified }\end{array}$ & $\begin{array}{l}\text { 19. SECURITY CLASSIFICATION } \\
\text { OF ABSTRACT } \\
\text { Unclassified }\end{array}$ \\
\hline
\end{tabular}

